\title{
PENGANTAR REDAKSI
}

Sidang redaksi Jurnal Profetika pada edisi ini menerbitkan Special Issue (Edisi Spesial) tema kajian keislaman dari berbagai sudut pandang. Edisi spesial ini dimuat dalam Vol. 21, No. 1, Special Issue 2020 mengangkat beragam karya tulis ilmiah dari berbagai kalangan baik dari pakar maupun akademisi. Pembahasan pada edisi spesial ini mencakup berbagai disiplin ilmu keislaman, baik hukum Islam, pemikiran Islam, ekonomi Islam, dan pendidikan Islam. Berbagai disiplin kajian tersebut telah direview oleh tim ahli dan mendapatkan perhatian serius demi terwujudnya pemahaman yang komprehensif demi kemajuan studi Islam di Indonesia.

Edisi khusu ini dimulai dengan artikel bernuansa syariah (hukum dan ekonomi Islam) yang ditulis oleh Amat Mulyoko dengan judul "Premarital of Private Education in Kantor Urusan Agama (KUA) Semarang District", kedua tema "Komodifikasi Nilai Islam dalam Fashion Muslim Di Instagram" oleh Khairul Syafuddin, Ni'amatul Mahfiroh, dilanjut pembahasan "Analisis Pernikahan Usia Dini Ditinjau dari Sudut Pandang Ekonomi, Sosial dan Religi: Studi di Purwodadi Grobogan" oleh Siti Fatimh Nurhayati, Indah Kurniasari, selanjutnya tentang ekonomi Islam berjudul "Konsep Uang dalam Perspektif Ekonomi Islam" oleh Muchammad Ichsan, dilanjut "Pemberian Mut'ah Dan Nafkah Iddah Dalam Perkara Cerai Gugat" oleh Heniyatun, Puji Sulistyaningsih, dan Siti Anisah.

Masih tentang syariah, artikel yang ditulis oleh Veni Soraya Dewi, Frisztina Anisa, Ade Vira Agustina berjudul “Implementasi Maqasid Syariah Pada Annual Report Bank Umum Syariah Sebagai Mitra Universitas Islami. Juga artikel dari Imamul Arifin, Andika Adinul Yahya, Muhammad Thoriq Azzam berjudul "Revolusi Yayasan Sosial Dan Kemanusiaan Terintegrasi Bagi Anak Jalanan dan Yatim Piatu Dalam Nilai-Nilai Islam. Itulah tema-tema tentang syariah yang dipublikasi dalam edisi spesial ini.

Artikel selanjutnya tentang education (pendidikan). Pertama tentang "Integrasi Ilmu Agama dan Sains: Studi Penulisan Skripsi di UIN Syarif Hidayatullah Jakarta" yang ditulis oleh Saifudin, dosen di UIN Syarif Hidayatullah Jakarta. Selanjutnya tentang "Pendidikan Multikultural Dari Perspektif H.M. Rasjidi" oleh Daru Nur Dianna. "Aplikasi Pembelajaran Pai Metode IBL (Inquiry Based Learning) Berbasis Zone Activity di Sekolah Dasar Lebah Putih Salatiga yang ditulis oleh Wahyu Budi Utomo, dosen di IAIN Salatiga.

Masih bertemakan pendidikan Islam, artikel selanjutnya berjudul "Strategi Pembelajaran Inovatif Pendidikan Agama Islam di SDIT Muhammadiyah Sinar Fajar Dan SD Muhammadiyah PK Klaten" yang ditulis oleh mahasiswa di Universitas Muhammadiyah Surakarta beserta dosen pembimbingnya Sigit Trihariyanto, Eko Supriyanto, Muthoifin. Dilanjut artikel dengan model yang hampir mirip oleh Agus Mulyadi, Eko Supriyanto, Muthoifin berjudul “Upaya Peningkatan Mutu Sekolah Di Smp Muhammadiyah Sinar Fajar Cawas Dan Smpit Muhammadiyah An Najah Jatinom Klaten" selanjutnya tentang "Model Penjaminan Mutu Ketercapaian Kompetensi Dasar Dalam Sistem Pembelajaran Online Pada Situasi Work From Home (WFH)" oleh Dwi Astuti, Eko Supriyanto, Muthoifin.

Artikel terakhir, yakni yang ke-14 bertuliskan dengan gaya bahasa Arab, sebagai ciri khas Profetika, yaitu tetap meberi peluang artikel yang berbahasa Arab. Artikel ini berjudul: قاعدة) اقتضاء النهي الفساد و البطلان 》عند المذاهب الأربعة) و تطبيقاتها في المناكحات ditulis oleh Suranto beserta timnya, yaitu Imron Rosyadi, Muinudinillah Basri. 
PROFETIKA, Jurnal Studi Islam, Vol.21, No. 1, Juni 2020: 1-15

Demikianlah sekapur sirih dari tim redaksi, semoga di edisi khusus ini (Vol. 21, No. 1, Special Issue 2020) dapat memberikan sumbangsih yang mencerahkan kepada para pembaca dan masyarakat pada umumnya dalam memahami berbagai perkembangan wacana dan dinamika Islam, utamanya yang terkait langsung dengan tema-tema yang dimuat dalam jurnal ini.

Redaksi 